\title{
Closing the attainment gap for students from black and minority ethnic backgrounds through institutional change
}

Mcduff, Nona, Tatam, John, Beacock, Owen and Ross, Fiona

\begin{abstract}
UK universities are achieving some success in attracting increasingly diverse undergraduate cohorts. However, there is compelling evidence that students from black and minority ethnic (BME) backgrounds do much less well in their final degree classifications than their White counterparts, even when entry qualifications are taken into account. This attainment gap has, until recently, not received the attention it deserves. This paper describes how Kingston University has substantially narrowed this gap through an outcome focused institutional change programme. The paper draws upon race theory and describes a multifaceted approach to change that involved: defining the scale of the problem; using a value added metric; engaging the university leadership and academic community; agreeing goals, interventions and outcomes/targets. Over a five year period of collecting data on value added scores on BME attainment, there is evidence of very significant year on year improvement. The paper discusses the challenges of complex change and the initial reluctance of staff to discuss issues around racial disadvantage. It highlights some implications for higher education institutions, especially those in the UK, seeking to close differentials in attainment.
\end{abstract}

(179 words)

Key words: black and minority ethnic (BME); attainment gap; value added; institutional change; inclusive curriculum 


\section{Introduction}

UK universities can point to some success in widening the participation of Black and Minority Ethnic (BME) students: a slightly higher proportion of UK domiciled BME school leavers now attend British universities than their White counterparts. However, where higher education has failed is in ensuring that those BME students are successful. The national picture shows BME students are much less likely to achieve a degree, to gain a first or upper second, to move on to graduate employment or study, or to obtain any employment (Higher Education Funding Council 2013). Yet this is an area which until recently has received relatively little attention.

This paper describes how Kingston has both set about raising awareness of the attainment gap and reducing it through an innovative institutional change programme that measures outcomes using value added data. The approach is included as an illustrative example in a recent Universities UK report (UUK 2016).

The paper starts with a review of the literature that highlights the range of explanations for the attainment gap and outlines the race theories that grounded our approach to strategic organisational change. The focus was on the whole institution rather than local and marginal interventions. We describe the change interventions, the value added outcomes, the greater reluctance of staff to discuss attainment in relation to ethnicity as opposed to gender or class, and end by identifying some propositions that have implications for policy and practice for sector agencies, the committee of university chairs and higher education institutions.

\section{The BME attainment gap}

Over the ten-year period from 2003/4 to 2013/14, the total proportion of BME students in Higher Education increased from $14.9 \%$ to $20.2 \%$ (ECU 2015), although this increase is not the case for all ethnic groups or at all universities (Runnymede 2015). Whilst ethnic minorities now constitute a higher proportion of participants at the most selective institutions than they did six years ago, there is still significant underrepresentation of some groups. Black Caribbean and Other Black pupils, for example, are still significantly less likely to attend a selective institution than their White British counterparts (BIS 2015:13). Employment outcomes, influenced by degree outcomes, are also poor for BME students across all groups; with the biggest gaps for Chinese and black African graduates (UUK 2016:19). The term BME is therefore problematic (Singh 2009) and may disguise issues of 
intersectionality or super-diversity (Vertovec 2007). Despite its limitations, in this paper we use the term as it is widely recognised and describes patterns of marginalisation and segregation caused by attitudes toward an individual's ethnicity (UUK 2016).

Widening participation in higher education has been a feature of government policy in the UK and Europe for the last fifteen years. It promotes the increase of numbers of young people entering education, but also the proportion from under-represented groups (Burke 2012). There has been success in increasing both the number and diversity of young people entering university and this has contributed to the fact that Chinese, Indian and Black African groups living in the UK are now more likely to have a degree level qualification than the white population, although migration policies which have encouraged highly qualified migrants have clearly also been a factor (Finney and Lymperopoulou 2014).

The story on outcomes for BME students at university is much less positive. In this paper we focus on the difference between the proportion of White and BME students who achieve a first or upper second degree, widely described as the BME attainment gap. Of all UK domiciled students graduating in 2015 across the UK, 77.1\% of White students achieved a $1^{\text {st }}$ or 2:1, but only $61.8 \%$ of BME students - a gap of 15.3 percentage points (Equality Challenge Unit 2016). Or, to put it another way, 25\% more of the White student cohort received a $1^{\text {st }}$ or $2: 1$ than the BME student cohort.

Nationally there is variation in attainment across the broad ethnic groups, with Chinese students doing best followed by those of Indian heritage, Bangladeshi, Pakistani, with Black Caribbean and Black African doing least well. (Equality Challenge Unit 2016).This hierarchy is very similar in the compulsory education sector in England. Again, Chinese pupils do best followed by Indian and Bangladeshi, but in schools, Black African pupils achieve more highly than Pakistani or Black Caribbean pupils (DfE 2015, Burgess 2014). However, the major difference between schools and universities is that in schools Chinese, Indian, Bangladeshi and Black African students all out perform White British pupils (in 2014 $74.4 \%$ of Chinese and $56.8 \%$ of Black African pupils achieved 5 A*-C GCSEs, compared with 56.4\% White British) but in UK universities all these groups attain less well than white students (of 2015 UK domiciled graduates $77.1 \%$ of White British students were awarded a $1^{\text {st }}$ or $2: 1$ degree as against $70.6 \%$ of Chinese and $49.7 \%$ of Black African students).

Despite the scale and persistence of the attainment gap in the UK it has until recently received relatively little systematic or institution wide intervention in higher education and 
has tended to be explained in terms of student characteristics, the 'student deficit', rather than institutional shortcomings.

Kingston University (Kingston) is a widening participation university and more than $50 \%$ of its student population are from black and minority ethnic backgrounds.

\section{What accounts for the BME attainment gap?}

The literature reveals there is growing awareness across the sector that the causes of the attainment gap are complex and multi-causal. Initial explanations tended to be on the 'deficiency' of the student in relation to factors such as entry qualifications, socio economic status, work and family commitments or cultural differences. However, some large and wellcontrolled studies, for example Broecke and Nicholls (2007), and more recently Hefce (2015) have convincingly challenged this view. The Hefce report compared results of over 280,000 students graduating from English universities in 2013-14. It showed that the attainment gap of 16 percentage points in those obtaining a first or upper second class degree (76\% White vs $60 \% \mathrm{BME}$ ) was only reduced to 15 percentage points when controlling for entry qualifications, age, disability, a participation of local areas measure, sex, subject studied, previous school type and institution attended (Hefce 2015). The gaps ranged from five percentage points for graduates with four As at A-level, to 18 percentage points for graduates with non-A-level entry qualifications (Hefce 2015).

While growing and cumulative evidence confirms that young people from BME backgrounds are doing less well at universities, it raises questions about contextual factors, and specifically what is the effect of the university environment, which is geared for "traditional" young White, middle class students? Studies have found a link between building a feeling of belonging and identity with an institution and academic success (Stuart, et al.2009b). A number of factors attributed to exclusionary practices are described in the literature, for example, some student union activities, such as drinking alcohol, which excludes Muslims (Singh 2009; Stuart, et al., 2009a), and perceptions and reporting of racism on campus highlighted by the National Union of Students (NUS 2011, Cousin and Cuerton, 2012). Challenging racism can be particularly difficult where academic staff see the problems of BME students "fitting in" and attainment to be the result of wider societal issues rather than the institution (Stevenson, 2012). It is for these reasons that in addition to addressing the knowledge and skills required of staff, we concluded that a systematic institution-wide 
approach was necessary to address the attainment gap (Berry \& Loke 2011, Stevenson, 2012).

\section{Drawing upon race theories to shape our approach.}

The literature on race, inequality and education is extensive, complex and contested. We drew from three main theoretical perspectives to inform our approach to change: 1) deficiency theories 2) bias theories and 3) structural theories. Deficiency theories focus on the minority group and claim that racial inequalities stem from biological or cultural differences (Conyers 2002). Although criticised for victim blaming, we argue these ideas underpin many established attitudes in higher education, in particular, as described above, the student deficit model, which we challenge in this paper as being insufficient in explaining the attainment gap.

Bias theories rest on the belief that racial inequality is the result of bias or prejudice held by the dominant group. Studies that have related the concept of bias to universities have highlighted intergroup bias, for example the systematic tendency to evaluate one's own membership group (the in-group) or its members, more favourably than a non-membership group (the out-group) or its members' (Hewstone, Rubin and Willis 2002 p. 576). Intergroup bias which results in discrimination incorporates three different components: prejudice, stereotypes and attitudes (Mackie \& Smith, 1998) and each produce cognitive (thoughts and beliefs) and affective (feelings and emotions) reactions (Dovidio \& Hebi, 2004 p.12-13). However, bias theories have been criticised as structurally and historically incomplete, limiting their importance as explanations of racial inequality (Conyers 2002:251). Racism can continue to operate in a higher education setting, even when overt prejudices and discriminatory practices are no longer legally or socially permissible, through unconscious or implicit bias (Cornish \& Jones 2013). We therefore took the view that highlighting bias and the way it can affect student success was essential. Our approach to change was aligned with the university's commitment to addressing race inequality and increasing BME students' aspirations and sense of belonging.

The third set of theoretical ideas that informed our thinking were structural perspectives. These focus on claims that racism is maintained by racist economic, educational and institutional factors. Critical race theorists have long argued that a number of features cause racial inequality and that they endeavour to expose the way in which race inequality is maintained through the operation of structures and assumptions that appear normal (Rollock 
and Gillborn 2011: 1). Ladson-Billings and Tate proposed that Critical Race Theory (CRT), a framework developed by legal scholars, could be employed to examine the role of race and racism in education' (Dixson \& Rousseau, 2005, p. 8) suggesting therefore that if race matters so does racism. CRT highlights the importance of understanding racism within its social, economic and historical context thus challenging the assumptions held about meritocracy and neutrality which have been presented as arguments against the widening participation agenda (Brinks, 2009) . CRT proposes that Whiteness is socially constructed and refers to a set of assumptions, beliefs and practices which makes the interests, behaviours and perspectives of White people normative. Our experience shows that challenges to that normative practice can often lead to cognitive dissonance, manifested by defensive arguments about fairness, colour blindness and even resistance.

Other approaches and views on race have challenged the efficacy of CRT. Multicultural education is a paradigm which intended to ensure students from diverse ethnic and social class backgrounds and more recently those of different gender and sexual orientation, experienced educational equality. Whilst the aim may have been far reaching, in practice examples of multiculturalism are too often expressed in terms of food or music or folktales. Ladson-Billings and Tate (1995, p.62) purport that this paradigm "attempts to be everything to everyone and consequently becomes nothing for any one, allowing the status quo to prevail". Notwithstanding the benefits of multiculturalism which is a core tenant of university diversity work we, like CRT scholars, argue this paradigm lends itself to superficiality, distracts from the need for systemic change and prevents the real discourse about race and racism which is key to the step change that is needed to remove the attainment gap.

The role of social class in explaining differences in performance and success has challenged CRT's focus on whiteness. Hill (2009) while welcoming the anti-racism that CRT promulgates, is critical of its over emphasis on 'white supremacy'. He suggests that statistical analysis which shows that race trumps class in terms of underachievement at 16+ exams in England and Wales is in fact misleading. Hill argues that working class underachievement as well as underachievement by some minority ethnic groups is well documented. The notion of class as the major determinant of differential attainment in degree outcomes was commonly articulated by staff in the institution and more broadly the focus of early widening participation endeavours. 
In his exploration of intersectionality and CRT, Gillborn (2015) suggests that Crenshaw's view of intersectionality had been diffused and that it was important to return to it. Crenshaw who formally introduced the notion of intersectionality into gender theory provided insight into the impact of the interplay between these two variables. Gillborn draws upon Crenshaw's work with the African American Policy forum to provide a helpful interpretation of the impact of intersectionality. In short the forum states that perceived membership of a group exposed members to bias. Given that people are members of multiple groups exposes them to a variety of biases. Intersectionality has undoubtedly provided a more sophisticated look at student performance in higher education in terms of race, gender and class and more recently extended to other protected characteristics (Equality Act, 2010). Gillborn in his exploration of the utility of intersectionality as an aspect of CRT, argues that though intersectionality is important in understanding race inequality, racism itself retains its centrality in terms of differential experiences.

We remain convinced of the currency of CRT in exploring and addressing the BME attainment gap. Whilst CRT is a framework which helps us to move away from the student deficit model, we concluded that it was also important to bring to the surface the other perspectives on race inequality and manage these conversations carefully.

In summary, our strategies to tackle the attainment gap are informed by the critical literature on race equality with particular attention to assumptions (including colour blindness and racial climate) institutional structures, barriers, knowledge and skills.

\section{The approach to change.}

Our aim is to improve success in the academic attainment of BME students. We have set out to do this through institutional cultural change including establishing the reduction of the attainment gap as an institutional priority with a Board level Key Performance Indicator (KPI) measured by a Value Added score, explained below. We adopted a multifaceted approach that was longitudinal and took account of complexity after Van de Ven et al (1999) and Scott Poole and Van de Ven (2004) and adopted the systematic and planned efforts required for organisations with increased diversity (Gilbert et al. 1999). We describe the change process in terms of initiation, development, implementation and impact.

\section{Initiation - getting started}


The initiation period of change is often, according to Van de Ven et al (1999), an extended gestation of disconnected activities that coalesce following a trigger/shock. Kingston had positioned itself since the turn of the century as a widening participation university and there had been regular reports on the extent of the wide gap in attainment outcomes for students from BME backgrounds. This included an external and independent review, which caused disquiet and demonstrated differing levels of awareness of the attainment gap (Leathwood et al 2011) but this was not acted on at the time. It took new leadership of the institution to initiate the momentum for change and gain support from the governors in early 2012. A mandate was given to develop a robust metric and an institutional level achievement plan, and the vice chancellor consistently communicated this across the university.

\section{Development - getting the metric right - using Value Added data}

An immediate challenge was supporting institutional readiness for change by using student outcome data for raising awareness of the attainment gap. We did this in a variety of ways, but began by using imagery of the student journey (Figure 1). Using Higher Education Statistical Authority (HESA) attainment gap data for Kingston, our comparator group and the sector, we designed a map of the student journey to promote conversations with senior staff, asking the question: if the journey is the same, why is the outcome so different?

Insert Figure 1 here

For some staff it was clear that the sector measurement of the attainment gap was problematic because it allowed the rationalisation, or explaining away, of the gap through differentials in entry grades, subject of study and socio economic backgrounds. To counter this tendency, a key component of the Kingston approach has been the development and use of Value Added (VA) data, as created for The Guardian newspaper league tables. We see the VA data as part of the intervention or implementation of change. The key to the VA approach is that it enables the institution to create a story for each student by taking account of prior entry qualifications and subject of study when assessing his or her degree attainment. It has proven to be both a very powerful way of presenting the attainment gap and communicating this to staff. The use of VA measures is gaining increasing interest as policy and practice is developed in the new Higher Education and Research Bill 2016-17, and in particular the Teaching Excellence Framework, currently passing through the British Parliament. 
VA scores are calculated by taking actual degree outcomes for all graduates across higher education across the UK for the last five years, broken down by entry qualifications and subject of study, to arrive at a probability that a given student will achieve a 1 st $/ 2: 1$ degree. Aggregating these probabilities produces an 'expected' percentage for a given cohort of students who should achieve a $1^{\text {st }} / 2: 1$ degree. If the cohort achieves this percentage, the VA score is 1.0. For percentage attainment above or below the expectation the VA score is proportionately greater or less than 1.0. VA data has been made available for eight years broken down to University, Faculty, Department and Course levels.

For Kingston as a whole in2011/12, given their entry qualifications and subjects of study and based on the previous five years results across higher education, $63 \%$ of our BME students would have been expected to get a 1st/2:1 degree. Ultimately, only $45 \%$ did, giving a Value Added Score of 0.72 . In contrast, while $65 \%$ of our white students were expected to get a 1st/2:1 degree, $74 \%$ actually achieved this, giving a Value Added Score of 1.16 and a difference in attainment between white and BME students of 29 percentage points. This is shown in Figure 2. Over the five years from 2011/12 to 2016/17 the VA score for BME students has risen year on year from 0.72 to 0.99 while the score for white students has changed little from 1.16 to 1.13. In 2016/17 70\% of BME students achieved a first or 2:1 as against $81 \%$ for white students, a gap of 11 percentage points, down from 29 in 2011/12.

The University's KPI is to achieve a VA of 1.0 for BME students graduating in 2018/19 i.e. BME students should achieve the same percentage of 1st/2:1 degrees as the national average for all students with the same entry qualifications studying the same subjects. This has almost been achieved by 2016/17.

Figure 2: Kingston University Value Added scores for White and BME graduates 2011/12 to 2016/17.

Figure 3: VA data for a department and associated pathways by White and BME graduates $2011 / 12$ to $2016 / 17$.

\section{Implementation}


The implementation was multifaceted and targeted at the level of the institution and the individual. Our plan had three streams (Figure 4), targeted at: improving institutional systems and processes, engaging academic and professional communities and involving students:

- Improving institutional processes

- Enhancing the knowledge and skills of staff and students

- Better supporting BME students

Insert Figure 4 here

\section{Improve institutional processes}

In March 2014 the Board of Governors agreed to adopt an institutional target, KPI, an achievement plan and a process of calling the whole institution to account on progress. This made Kingston the first large Higher Education Institution in the UK to have the attainment gap as an institutional KPI and triggered radical changes to systems and processes.

Firstly, we embedded the KPI target and individual course metrics in university planning processes. Secondly, equalities considerations became part of the university academic progression and promotion framework and the processes of recruitment and promotion. Thirdly, to avoid marginalisation of the activity and a perception that it was just the "baby" of the equality and diversity team we ensured accountability for outcomes was "everyone's business" by establishing a cross-institutional steering group. Finally, and aligned to these changes, the development of Kingston's Inclusive Curriculum Framework (McDuff and Hughes, forthcoming) means that course teams and panels involved in validation, course monitoring and internal subject reviews must use the framework to demonstrate and assess how inclusivity is built into every level of learning and teaching.

\section{Strategies to enhance knowledge and skills of staff and students}

Learning and teaching is clearly central to the institution's relationship with BME students. Enhancing the knowledge and skills of staff with sensitivity, context and 'what next' resources has therefore been a primary focus. In designing the programme of activities, we took particular account of staff expectations and perceptions of race and inequality while recognising that the data in itself does not create engagement. For that to happen it needs to be compelling and must also provide an opportunity for analysis and learning. Personal 
delivery of the data to over ninety meetings of targeted course leads, schools and departmental away days has allowed us to provide bespoke feedback and demonstrate the facts of under attainment. It has also provided academics with the opportunity to question and discuss the validity and significance of the data. Emails can be ignored, but through conversations in the safe environment provided by these meetings, we have been able to bring even the most removed academics to a level of engagement, enabling initial scepticism, sometimes shock and disbelief, to be heard and addressed; for the research evidence to be explored; and the support available to be explained. While this approach is labour intensive and requires skill, sensitivity, and a familiarity with the data and the research, it is unlikely we would have moved beyond the stage of denial and reached the level of academic engagement across the institution needed to effect change without it.

Our principal interventions, in addition to these course team meetings around the VA data were: sustained communications by the Vice Chancellor about the importance of acknowledging race inequality; collegiate discussions, through workshops on the inclusive curriculum, around improving the racial climate and creating a sense of belonging and expectation to succeed for BME students and staff; and group workshops that explore unconscious bias and how its negative impacts can be mitigated. Priority was given to those course teams with the largest attainment gap and the $\mathrm{VC}$ wrote to all these teams making clear his expectation that they would take part in the workshops. While providing a menu of actions is necessary, it was also recognised that leaving the opportunity for academics to create and decide upon their own actions based on their learning from the conversations around the data and its significance was also important.

\section{Raising knowledge and skills of students}

We felt it was critical to raise the awareness of students about the sector's struggle with the attainment gap, the approach their university was taking and the ways they can get involved in making change happen. Activities have included working closely with the student union, holding briefing and discussion sessions with over 400 course representatives and training students to co-deliver training and engage in co-curriculum development.

Our strategic approach to supporting BME students has been to align the University's Access Agreement to the KPI. There are two things to note; firstly, the KPI has driven us to invest in activities that are more relevant and targeted to our BME students, and secondly to evaluate all activities to understand their impact on BME students and to help us to make decisions 
about continued funding. Principal initiatives (some of which were already running and folded into our institutional improvement programme) include:

- Student Academic Development and Research Associate Scheme (SADRAS) - in which students are funded to collaborate with staff on academic research projects that develop their skills and confidence. During the 2015/16 academic year eight new research projects focussed on the BME attainment gap.

- Taking Race Live (TRL) - which promotes collaboration with staff and students across Sociology and Music (and previously with Drama) to promote and support discussions about race. The success of this event in raising assessment scores is evidenced by Minors et al (2017).

- Academic Multi-cultural and Diversity Programme - which aims to build students' strong awareness of how culture and experiences shape perceptions of self and others, and shapes their worldviews. As a result of the positive evaluation these workshops they have now been embedded in a range of modules across three of five university faculties for the 2016/17 academic year.

- Compact Scheme - which delivers a programme of activities designed to support student's transition into higher education. Of the 1000 students in the 2015 scheme, $80 \%$ of BME compact students were eligible to progress compared to $76 \%$ of BME students from the wider UG student cohort.

- Beyond Barriers student equality mentoring schemes - BME students are matched with mainly external mentors who work with them to increase their confidence, self-belief, aspirations and attainment. Following the completion of the mentoring scheme, the 66 level five students that participated saw a 4\% increase in their average module results compared to level five students who did not participate.

\section{Discussion: closing the gap - engaging staff and promoting constructive discussion around race}

We have argued that the BME attainment gap is a major challenge for HE across the UK. At Kingston, we can point to real progress over the last five years with the VA score for BME students improving year on year from 0.72 to 0.99 and the gap between white and BME students achieving a first or 2:1 falling from 29 to 11 percentage points. . 
We believe that our success so far, and the distinctive nature of our approach is (a) we have adopted a systematic institution wide approach, embedding the KPI in institutional processes, and (b)we have developed the VA metric, which properly applied, has been a very powerful contributor, raising staff awareness about the reality of the gap and engaging them in constructive discussions about how to address it. We have recently received Hefce Catalyst funding to share our VA methodology and Inclusive Curriculum Framework with six other HEIs.

Staff engagement is key. In this section, we discuss our successes but also the barriers created by a focus on a 'colour blind' approach and a reluctance to discuss race.

While staff have had a general awareness of an attainment gap it is seeing clear evidence that it is affecting their courses and their students that has proved critical. Follow up with course and module teams shows that $92 \%$ of those responding to an evaluation questionnaire indicated that the VA score was either helpful or very helpful in demonstrating the attainment gap, and 54\% of respondents would utilise the support options available to them. Following the first round of these academic support meetings, many course teams have shown a commitment to increasing their skills and knowledge of diversity issues by attending the workshops provided. To date 308 academics have attended workshops at a capacity of $78 \%$. 104 staff have been to a session on the Inclusive Curriculum and 146 have attended unconscious bias workshops.

However, the work to engage staff has to be ongoing. As reported in the wider literature some academics believe that lower levels of attainment of minority ethnic students were 'perhaps not so important to them' (Mountford-Zimdars 2015 p.42). We had to make sure our strategies aligned staff behaviour with the University's core value of diversity. Our key message, driven by the University Strategy, was that when a student does fail or drop out, we will treat this as a failure of the University.

Our conversations with course teams and staff across the university revealed a reluctance to talk about race and racism. Conversations about gender appear to be easier than those about race even though the gender attainment gap is very much smaller than the ethnic gap (at least at Kingston). There was also very little research to draw upon and support the need to discuss race and its implications for higher education. Harper's (2010) review of 225 academic papers asked how higher education scholars discuss and make sense of race-related findings that emerge in their studies. He reflected that instead of viewing racial differences as by- 
products of institutionalized racism that requires systemic organizational change, authors routinely suggested approaches that had little to do with investigating and responding to the realities of race on campus. This is a view reinforced by Rollock (2015) and Loke (2015). Race is a more difficult, controversial and uncomfortable subject to discuss than gender and academics fear saying the wrong thing. (Rollock notes the criticism of the actor Benedict Cumberbatch for using the term 'coloured' which drowned out the fact that he was making a bold statement about injustices in his own industry). Universities tend to view themselves as highly liberal spaces and are therefore reluctant to see the cause of the "race problem" as lying, even to some extent with the institution. Rather they point to student or staff deficits in terms of the right grades or mix of subjects, or the lack of confidence of BME staff to go for promotion.

It can also be argued that, at least until recently, the equality agenda in universities has focused more on advancing female staff and supporting female students in Science and Engineering than addressing the clear deficits in terms of ethnicity. Only in the last two years has the well-established Athena Swan Charter, which focuses on gender and is linked to research funding opportunities, been matched by the Race Equality Charter (http://www.ecu.ac.uk/equality-charters/athena-swan; http://www.ecu.ac.uk/equalitycharters/race-equality-charter).

At Kingston where BME students are the majority, we needed to invest effort to encourage staff and ultimately students to discuss issues around race. We heard the term colour blind from staff to describe their well-meaning relationships with students. Apfelbaun (2008) describe strategic colour blindness as the pattern of behaviours used by White people toward people of colour to minimize differences, to appear unbiased, to avoid interactions with people of colour, to not acknowledge race-related topics, and even to pretend not to see the person's race. However, fear of appearing racist can result in unintended consequences with those who attempt to appear unbiased often appearing inauthentic, distant and perceived as more racist.

Sue (2009) argued that race talk has the potential to open a "can of worms" through cognitive dissonance as it moved White staff beyond their fear of appearing racist to actually being a racist. The teachings of democracy, equity, and equal access and opportunity which Whites profess to hold can be seriously challenged in race talk. It was our experience that to avoid this can of worms, the actual avoidance of race talk in a situation where it is deemed 
important and appropriate tends to make people of colour feel silenced and invalidated (Shelton et al 2005). Therefore, when creating our approach we knew that if we wanted our staff to have the knowledge and skills to create an environment where BME students felt they mattered, then in addition to accepting the concept of bias, we had to systematically create an institutional dialogue on race without being divisive and without substituting the student deficit model for a staff one.

More recently, the Inclusive Curriculum workshops include a debate about the role of the academic in addressing social issues particularly in subjects that do not automatically lend themselves to such discussion. Staff are also steered towards other dimensions of the inclusive curriculum framework such as assessment and delivery. Cousin and Cureton's (2012) study suggests that students perform better when the assessment types conform to their prior experience. We argue this suggests that staff need to make sure students learn new skills prior to taking their formal assessment. We stress that delivery is also a key aspect of the lecturer's role and that whilst content is important it needs to be accompanied with activities that encourage students to reflect on their relative as well as absolute progress. In so doing, lecturers are developing skills that create confidence and negate stereotyping/limiting self-perceptions.

The role of positive or targeted action continues to be a point of debate at Kingston for race more than for gender. We found three main viewpoints. Firstly, targeted action can contribute to building a divide between communities and may be detrimental to efforts to create an inclusive environment. Secondly, targeted action may confirm stereotypes, be self-fulfilling and there is evidence that students do not want it (Stevenson, 2012). Thirdly, there is the view that targeted action is necessary when resources and time are limited. Our approach seeks to strike a balance between universal and targeted approaches, as we outlined in Kingston's Race Equality Charter Mark application (2015).

A holistic approach to the gap has quite rightly also focussed Kingston's discussions on the lack of BME representation in both academic and professional staff groups. In addition to equity considerations for staff, there is a growing interest in the role of BME staff in the success of BME students and the importance of a more diverse academy for the preparation of students in a pluralistic society (Umbach, 2006). One of the actions to address this was to use the new Academic Progression and Promotion procedure to raise the lack of diversity in senior academic roles and deliver training on unconscious bias for panel members. 


\section{Conclusions and key messages}

This paper reports on the process and positive outcomes from an institutional change programme. We conclude that there are four important factors that have contributed to change and deserve to be explored and tested further in future research. While student performance has improved considerably, as measured through the value added data, we recognise we do not know much about the interrelationships and which of these factors was most influential in the change.

\section{Ensuring an institution-wide approach}

Our first point and a prominent factor in change was the institution-wide approach driven by an institutional KPI. Senior leadership from the vice chancellor and the governing body demonstrating commitment has been key to the change process. However, leading from the top is not sufficient on its own, as any effective organisational change is dependent on people, their relationship with the wider university, with their students and with each other. Here the important lesson is not to underestimate the time needed to gain both understanding and engagement of academic and non-academic staff at all levels, and of students, not as a one- off, but as a continuous process.

Using value added data to highlight the problem and engage course teams. A second key message is that data is a powerful tool, when used in a conversation to make sense of a "wicked problem". It allowed us to move the argument on, beyond the differences in attainment due to different entry qualifications and the variation of performance across courses. As Value Added data was available at course level, it has proved a powerful way of presenting the evidence and engaging course teams. Staff who may have had a general awareness of the relative under attainment of BME students are frequently shocked and surprised when they see the data, which shows how much better their BME students should have been doing. Where data on relative attainment is presented, which does not take such clear account of entry qualifications, there is a risk of prolonged debate about the data and requests for ever more data rather than a focus on addressing the gap.

Powerful though it is, the data is principally a tool for developing conversations and resetting expectations. It needs clarity of presentation and opportunities for explanation. At the same time as presenting the data, it was important to discuss the evidence on the causes of the gap; to deal with initial reactions of denial or reluctance to discuss race; and to explore supportive 
solutions, such as unconscious bias and inclusive curriculum workshops. We learned it is vital to avoid any suggestions of apportioning blame. Presenting data through narrative in this way can help staff make sense of troubling performance outcomes. It needs time and skill.

\section{Ensuring a multifaceted approach based on evidence}

We argue through this paper that the causes of the attainment gap are complex, multifaceted and not fully understood. Solutions need to address the complexity and take a systems wide approach. Effective interventions are more likely if they are evidence based and multifaceted. The next stage is to evaluate success, not just in terms of student outcomes, but also in terms of staff knowledge and skills and organisational change.

\section{Capturing and disseminating notable practice}

Once staff have become convinced that there is a problem and are moved to take action, they need suggestions and examples of successful initiatives. Kingston has collaborated in a part Higher Education Agency funded project to share learning with two other post 1992 universities but this is an area where we need do more to capture notable practice both within Kingston, across the sector, and internationally. We have recently received funding for a large collaborative project involving six universities across the sector to test out the use of the VA methodology and the institutional change approach to produce some wider generalisable lessons. 


\section{References}

Apfelbaum, Evan P., Samuel R. Sommers, and Michael I. Norton. "Seeing race and seeming racist? Evaluating strategic colorblindness in social interaction." Journal of personality and social psychology 95.4 (2008): 918.

Berry, J. and Loke, G. (2011) Improving the degree attainment of Black and minority ethnic students. Higher Education Academy and Equality Challenge Unit. Available at:

http://www.ecu.ac.uk/wp-content/uploads/external/improving-degree-attainment-bme.pdf

BIS (2015) Socio-economic, ethnic and gender differences in higher education participation. Paper 185. Department of Business Innovation and Science, London

Brinks, C. (2009) 'Standards will drop': dispelling fears about the equality agenda in higher education. Available at

http://www.ecu.ac.uk/wpcontent/uploads/2009/01/E_for_E_The_future_of_equality_in_he.pd $\underline{\mathrm{f}}$

Broecke, S. and Nicholls, T. (2007) Ethnicity and Degree Attainment. Department for Education and Science Research Report No RW92. London. Available at:

http://webarchive.nationalarchives.gov.uk/20130401151715/http://www.education.gov.uk/pu blications/eOrderingDownload/RW92.pdf

Burke, P.J. (2012) The right to higher education: beyond widening participation. Routledge

Cornish, T. Jones, P. (2013) Unconcious bias and higher education. Equality Challenge Unit. Available at: http://www.ecu.ac.uk/wp-content/uploads/2014/07/unconscious-bias-and-

higher-education.pdf

Conyers, J.E, (2002) Racial inequality: Emphasis on explanations, The Western Journal of Black Studies Vol 26 No. 4, P. 249-254. Available at http://users.clas.ufl.edu/marilynm/Theorizing_Black_America_Syllabus_files/Racial_Inequal ity.pdf

Cousin, D. and Cuerton, G (2012) Disparities in Student Attainment, Higher Education Academy. Available at:

https://www.heacademy.ac.uk/sites/default/files/projects/Worlverhampton\%202010\%20DIS A\%20Final\%20Report.pdf

DfE (2015) GCSE and equivalent attainment by pupil characteristics: 2015, Department for Education, Published January 2015. Available at https://www.gov.uk/government/statistics/gcse-and-equivalent-attainment-by-pupilcharacteristics-2014

Dixson, A.D. , Rousseau C.K (2005) And we are still not saved: critical race theory in education ten years later. Race Ethnicity and Education Vol 8 No.1. 
Dovidio, John F, Hebi, M.R. Discrimination at the level of the individual: cognitive and affective factors, Dipboye, R.1. , Colella, A. (2005) Discrimination at Work: The Psychological and Organizational Bases

Equality Challenge Unit (2015) Statistical report 2015, Equality Challenge Unit. Available at http://www.ecu.ac.uk/publications/equality-higher-education-statistical-report-2016/

Equality Challenge Unit (2016) Statistical report 2016, Equality Challenge Unit. Available at http://www.ecu.ac.uk/publications/equality-higher-education-statistical-report-2016/

Finney, N., \& Lymperopoulou, K. (2014). Local Ethnic Inequalities: Ethnic Differences in Education, Employment, Health and Housing in Districts of England and Wales, 2001-2011. London: Runnymede Trust. Publication link: $\underline{3 b 2 f 6490-1686-4 d 4 a-87 a 0-1 a b 7 e 49 d f 7 f a}$

Gilbert, J.A., Stead, B.A., \& Ivancevich, J.M. (1999). Diversity management: A new organizational paradigm, Journal of Business Ethics, 21(1), 61-77.

Gilborn, D., (2015) Intersectionality, Critical Race Theory, and the Primacy of Racism Qualitative Inquiry, Vol.21(3), pp.277-287.

Harper, S. (2010) Race without racism: How Higher Education researchers minimize racist institutional norms. The Review of Higher Education, Fall 2012, Vol 36 No.1 p. 9-29.

Hefce (2013) Higher education and beyond: Outcomes from full-time first degree study. Issues paper 2013/15 Higher Education Funding Council, Bristol. Available at: http://www.hefce.ac.uk/media/hefce/content/pubs/2013/201315/Higher\%20education\%20and $\% 20$ beyond $\% 20$ Outcomes $\% 20$ from $\% 20$ full-time $\% 20$ first $\% 20$ degree $\% 20$ study.pdf

Hefce (2015) Differences in degree outcomes: The effect of subject and student characteristics. Issues paper 2015/21 Higher Education Funding Council Bristol.Available at: http://www.hefce.ac.uk/media/HEFCE,2014/Content/Pubs/2015/201521/HEFCE2015_21.pdf

Hewstone, M., Rubin, M., Willis, H. (2002) Intergroup bias. Annual Review of Psychology; 2002; 53, Science Database pg. 575-586.

Hill, D. (2009) Race and Class in Britain: A Critique of the Statistical Basis for Critical Race Theory in Britain: And Some Political Implications, Journal for Critical Education Policy Studies, 2009, Vol.7(2), p.1-40.

Kingston University Race Charter Mark (2015). Available at:

http://www.kingston.ac.uk/aboutkingstonuniversity/equality-diversity-and-inclusion/raceequality-charter-award/

Ladson-Billings, G. and Tate, W.F., (1995). Toward a critical race theory of education. Teachers college record, 97(1), p.47.

Leathwood, C, Hutchings, M. and Mansaray, A. (2011). Student Diversity and Success at Kingston University. An investigation of the progression and attainment of students from ethnic minority backgrounds to inform the development of teaching and learning strategy and practice. Final Report. Institute for Policy Studies in Education, London Metropolitan University. Available at 
https://committees.kingston.ac.uk/VCA/VCAAD/Committee\%20Papers/AD406a\%20\%20BME\%20-\%20Full\%20Report.pdf

Loke, G. (2015) Breaking the Race Inequality Cycle in Higher Education: A Change of Focus is Needed to Break the Statistical Groundhog Day in Aiming Higher ed Alexander, C.and Arday, J. Runnymead www.runnymedetrust.org/uploads/Aiming Higher.pdf

Mackie, D.M, Smith, E.R. (1998) Intergroup Relations: Insights From a Theoretically Integrative Approach. Vol 105(3), p. 499-529, Psychological Review.

McDuff, N., and Hughes, A. (forthcoming) Turning inclusive principles into inclusive practice: introducing an integrative and holistic Inclusive Curriculum Framework in Higher Education

Minors, H. J., Burnard, P., Wiffen, C., van der Walt, J. S., Shihabi, Z. (2017)

Mapping trends and framing issues in higher music education, London Review of Education

Mountford-Zimdars, A. (ed.) (2015) Teaching in the context of diversity: Reflections and tips from educators at King's College London. Higher Education Research Network Journal: King's College London.

Available at: https://www.kcl.ac.uk/study/learningteaching/kli/research/hern/hernjvol9.pdf

NUS (2011) Race for Equality. National Union of Students. Available at: http://www.nus.org.uk/PageFiles/12350/NUS_Race_for_Equality_web.pdf

Rollock, N. and Gillborn, D. (2011) Critical Race Theory, British Educational Research Association online resource. Available at https://www.bera.ac.uk/wpcontent/uploads/2014/03/Critical-Race-Theory-CRT-.pdf?noredirect=1] Last accessed [7.2.16].

Rollock,N. (2015) Why is it so hard to talk about race in UK universities? The Conversation http://theconversation.com/why-is-it-so-hard-to-talk-about-race-in-uk-universities-37299 [Last accessed 16.6.17]

Runnymede (2015) Aiming Higher, Race, Inequality and Diversity in the Academy, Runnymede Perspectives Series. Runnymede Trust

Scott Poole M., Vand de Ven A. (2004) Processes: theory and methods for research Handbook of Organisational Change and Innovation. New York: Oxford University Press

Shelton, J. N., Richeson, J. A., Salvatore, J., \& Trawalter, S. (2005). Ironic effects of racial bias during interracial interactions. Psychological Science, 16, 397-402

Singh, G. (2009) Black and minority ethnic (BME) students' participation in higher education: improving retention and success: A synthesis of research evidence. York: Higher Education Academy. Available at https://www.heacademy.ac.uk/sites/default/files/BME_synthesis_FINAL.pdf 
Stevenson, J. (2012) Black and minority ethnic student degree retention and attainment, Higher Education Academy, Higher Education Funding Council. Available at: https://www.heacademy.ac.uk/sites/default/files/bme_summit_final_report.pdf

Stuart, M., Lido, C., Morgan, J., \& May, S. (2009a). Student Diversity, Extra Curricular Activities and Perceptions of Graduate Outcomes, Project report for the Higher Education Academy, available at http://gala.gre.ac.uk/3232/1/HEA_project_report_2007_8.pdf

Stuart, M. et a.l (2009b) The Impact of Social Identity and Cultural Capital on Different Ethnic Student Groups at University: Full Research Report ESRC End of Award Report, RES-000-22-2485. Swindon: Economic and Social Research Council. Available at: https://s3-eu-west-1.amazonaws.com/esrcfiles/outputs/V98stuXupEOgSRdhDkrT7A/Vnz4RGjHzU6M16YK99hoDQ.pdf

Sue, D.W. (2013) Race Talk: The Psychology of Racial Dialogues, Anderson, Norman B. (editor), American Psychologist, 2013, Vol.68(8), pp.663-672 [Peer Reviewed Journal]

Umbach, P. The contribution of faculty of color to undergraduate education. Research in Higher Education, 2006, Vol.47(3), pp.317-345.

UUK (2016) Working in partnership: enabling social mobility in higher education. Universities UK. Available at http://www.universitiesuk.ac.uk/policy-andanalysis/reports/Pages/working-in-partnership-enabling-social-mobility-in-highereducation.aspx

Van de Ven A., Polley D., Garud R., Venkataraman S. (1999) The Innovation Journey. New York: Oxford University Press

Vertovec, S. (2007) Super-Diversity and its implications. Ethnic and Racial Studies, Vol. 30 No. 6 November 2007 pp.1024-1054. 


\section{Figures}

Figure 1: The student journey.

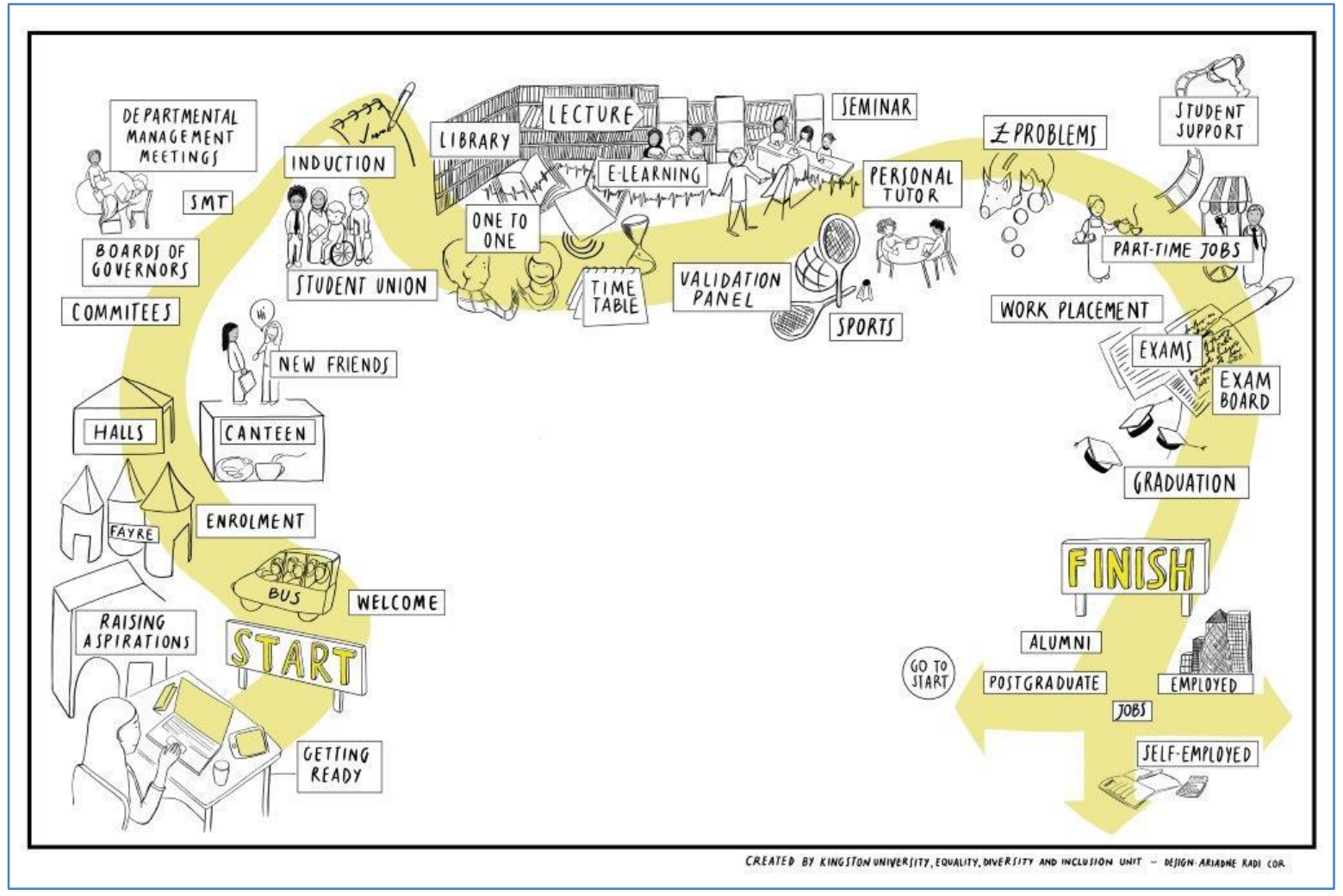

Figure 2: Kingston University Value Added scores for White and BME graduates 2013/14 to 2015/16.

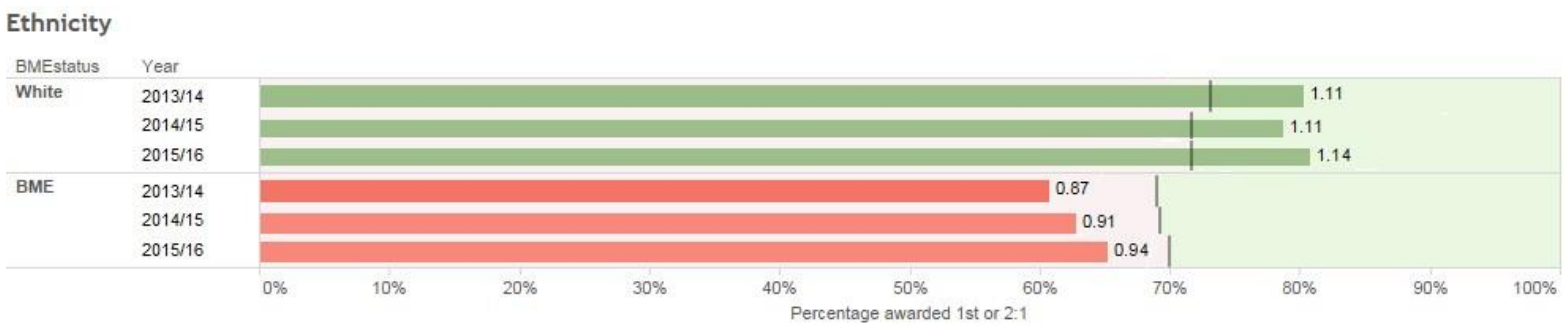

Figure 3: VA data for a department and associated pathways by White and BME graduates $2012 / 13$ to $2014 / 15$. 


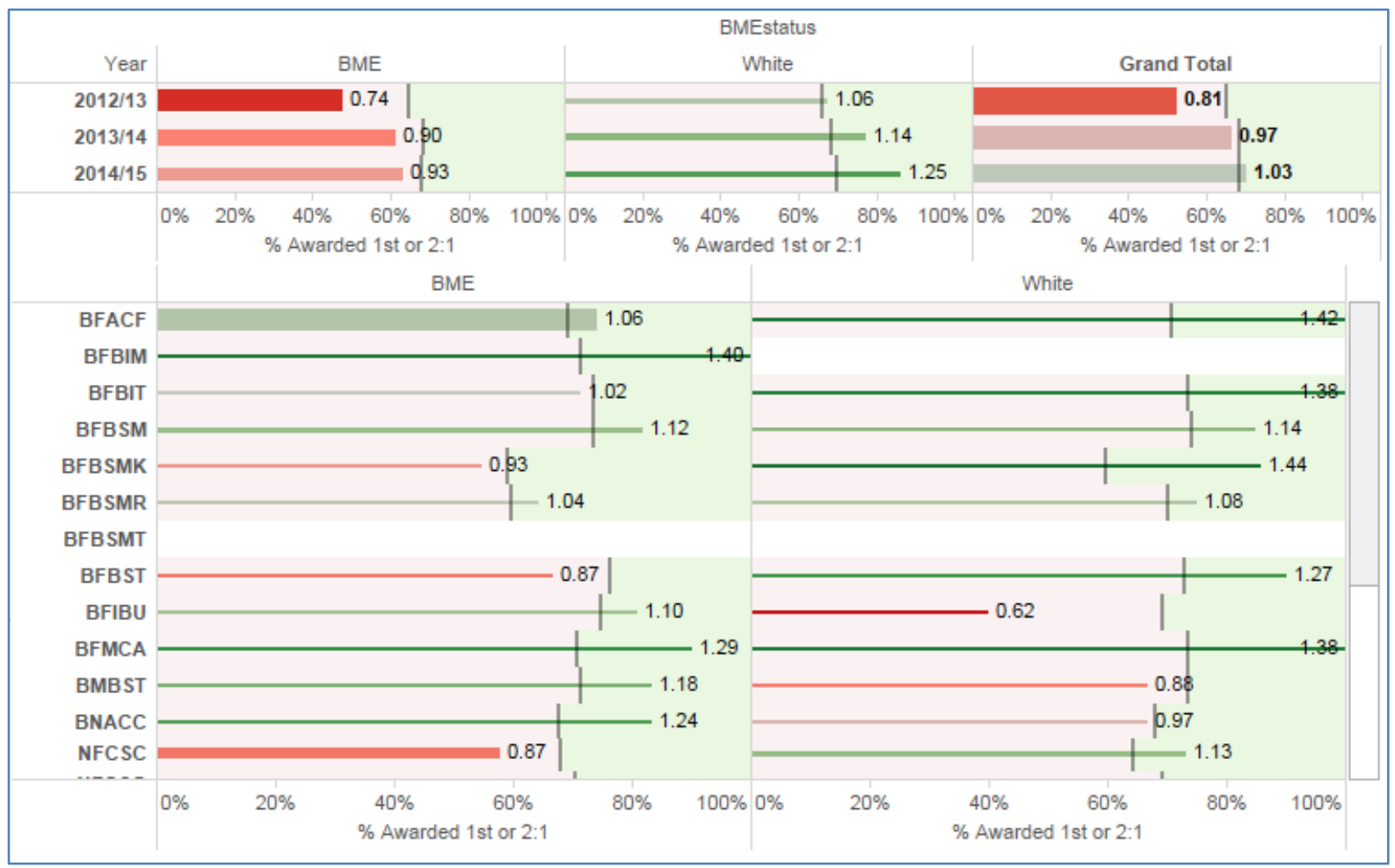

Figure 4: The three elements of Kingston University's approach

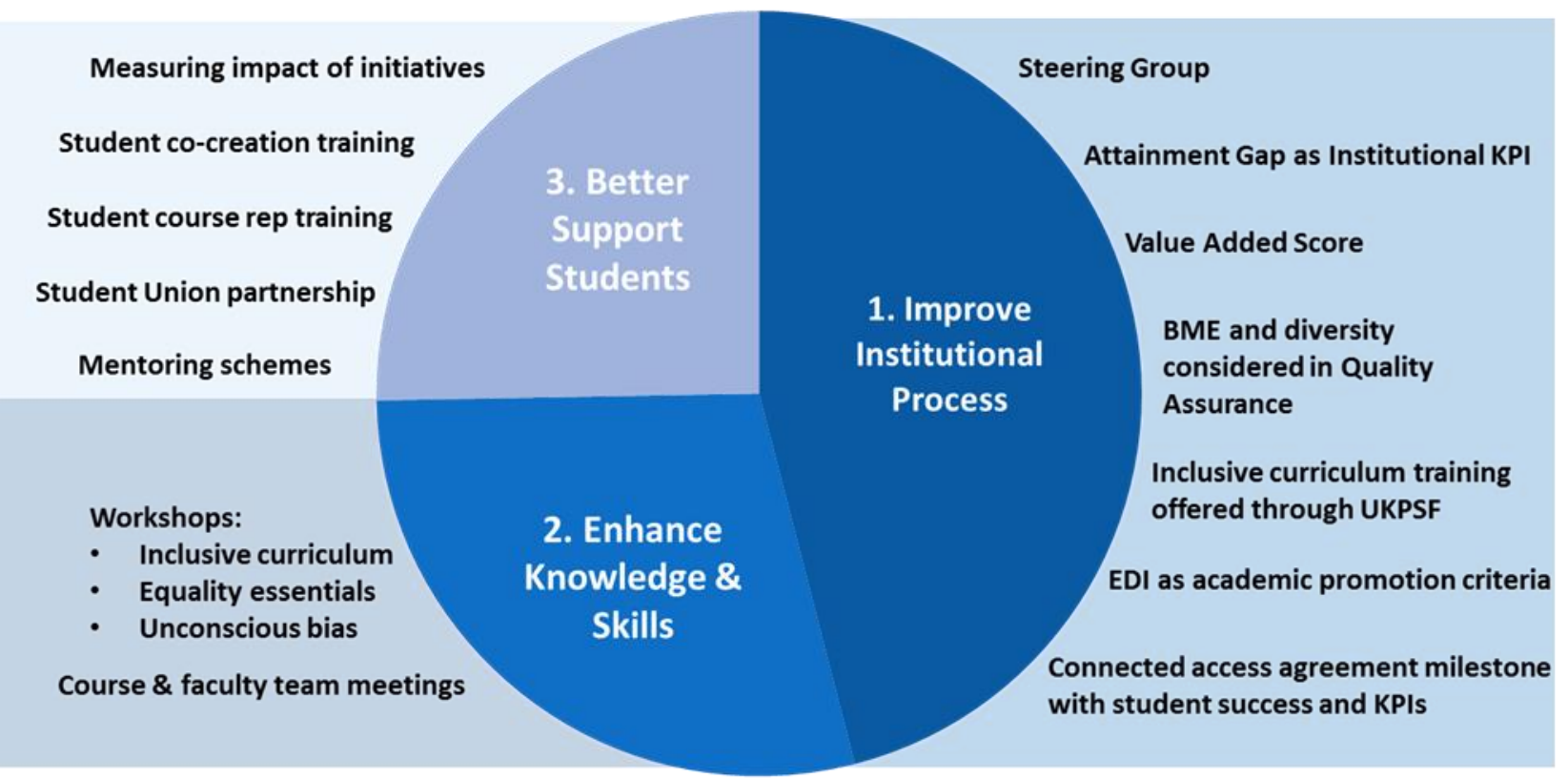

